\title{
M. tuberculosis kompleks izolatlarının antitüberküloz ilaçlara direnç oranlarında yıllara göre değişim;
}

\section{Sakarya}

Hüseyin Agah TERZi் ${ }^{1}$, Özlem AYDEMIR ${ }^{1}$,Engin KARAKEÇE ${ }^{1}$, Mehmet KÖROĞLU², Mustafa ALTINDIŞ

Tüberkülozda ilaç direnç sürveyansının yapılması tüberküloz kontrol ve tedavi programlarının temelini oluşturur. $\mathrm{Bu}$ çalışmada, laboratuvarımızda izole edilen $M$. tuberculosis kompleksi izolatlarının primer antitüberküloz ilaçlara duyarlılıklarının araștırılması ve direnç paternlerinin belirlenmesi amaçlanmıștır. Çalıșmada, 2012-2017 yılları arasında tüberküloz şüphesi ile laboratuvarımıza gönderilen 11194 klinik örnek değerlendirmeye alınmıștır. Tüberküloz kültürü ve duyarlılık testleri BACTEC MGIT 960 (Becton Dickinson, ABD) sistemi ile, üretici firmanın önerileri doğrultusunda gerçekleştirilmiştir. Çalışmaya alınan örneklerden $M$. tuberculosis kompleks olarak tanımlananan $466(\% 4,1)$ örneğe antibiyotik duyarlılık testi uygulanmıştır. Klinik örneklerde M. tuberculosis kompleks pozitifliği, 2012-2017 yılları arasında sırasıly; \% $4,5, \% 3,4, \% 3,5$, $\% 4,6, \% 5,4$ ve $\% 3,1$ bulunmuştur. İzole edilen M. tuberculosis kompleksi izolatları, 20122017 yılları arasında sirasıyla $\% 66,2, \% 90,7, \% 81,4, \% 78, \% 80, \% 74$ oranında tüm primer ilaçlara duyarlı bulunmuştur. En az bir antitüberküloz ilaca direnç oranı \%14,8 olarak bulunmuştur. Çok ilaca direnç ise \%4,1oranında bulunmuştur. Çoklu direnç daha çok 2012 yılında saptanmıştır. TB dışı mikobakteri saptama oranı ise \%0,4 olarak bulunmuştur. Tüberkülozda direnç paternlerinin izlenmesi, uygulanacak tedavi protokollerinin belirlenmesinde önemli olduğu gibi uzun vadede direnç gelişiminin önlenmesinde de yararlı olacaktır.

Anahtar Kelimeler: antitüberküloz ilaçlar, BACTEC MGIT 960 sistemi, direnç, Mycobacterium tuberculosis kompleks, sürveyans

Gönderi Tarihi:05.07.2018

Kabul Tarihi:13.09.2018

Online Yayın Tarihi:

DOI: $10.26453 /$ otjhs.441168

Sorumlu Yazar

Hüseyin Agah TERZI

Changes in antituberculosis drug resistance rates of $M$. tuberculosis complex isolates by years; Sakarya

Hüseyin Agah TERZİ ${ }^{1}$, Özlem AYDEMIR ${ }^{1}$, Engin KARAKEÇE ${ }^{1}$, Mehmet KÖROĞLU ${ }^{2}$, Mustafa ALTINDİ̧̧

\begin{abstract}
Surveillance of drug resistance in tuberculosis is an important component of the tuberculosis control and theraphy program. The aim of this study was to determine the susceptibilities of Mycobacterium tuberculosis complex isolates to primary antituberculosis agents and their resistance patterns. A total of 11194 samples which were sent to our laboratory for routine tuberculosis culture with the suspicion of tuberculosis clinically between 2012 and 2017 were included in the study. BACTEC MGIT 960 (BectonDickinson, USA) system was used for tuberculosis culture and susceptibility testing according to the manufacturer's recommendations. A total of $466(4,1 \%)$ M. tuberculosis complex were isolated from all samples and susceptibility testing was performed. $66,2 \%, 90,7 \%, 81,4 \%, 78 \%, 80 \%$, and $74 \%$ of the $M$. tuberculosis complex isolates were susceptible to all primary antituberculosis agents between 2012 and 2017 respectively. The positivity of the M. tuberculosis complex was found 4,5\%, 3,4\%, 3,5\%, 4,6\%, 5,4\% and 3,1\% between 2012 and 2017 respectively. Resistance to at least one drug was $14,8 \%$ and multi drug resistance was $4,1 \%$. Multi drug resistance was detected mostly in 2012. Mycobacterium other than tuberculosis was detected in 40 samples $(0,4 \%)$. Monitoring of resistance patterns in tuberculosis is important in determining treatment protocols and will also be useful in preventing the development of resistance in long term.
\end{abstract}

Article Info

Received:05.07.2018

Accepted:13.09.2018

Online Published:

DOI: $10.26453 /$ otjhs.441168

Keywords: antituberculosis drugs, BACTEC MGIT 960 system, Mycobacterium tuberculosis complex, resistance, surveillance

\footnotetext{
${ }^{1}$ Sakarya Üniversitesi Eğitim ve Araştırma Hastanesi, Tıbbi Mikrobiyoloji Laboratuvarı, Sakarya

${ }^{2}$ Sakarya Üniversitesi Tıp Fakültesi, Tıbbi Mikrobiyoloji Anabilim Dalı, Sakarya
}

Corresponding Author

Hüseyin Agah TERZI 


\section{GíRiș}

Tüberküloz (TB), Mycobacterium tuberculosis kompleksi (MTK) tarafından oluşturulan, insanlık tarihinin en eski ve en yaygın bulaşıcı hastalıklarından biridir. ${ }^{1}$ Genellikle akciğerleri tutan fakat tüm sistemleri de etkileyebilen TB'un tanısı ise şüpheli örneklerde aside dirençli bakteri görülmesi ve kültürlerinde üremenin olması ile konur. ${ }^{1}$

Dünya Sağlık Örgütü (DSÖ) verilerine göre 2016 y1lı itibariyle dünyada 10,4 milyon TB vakası olup, bunların 490 bini çok ilaca dirençli (ÇİD) olgularıdır. ${ }^{2}$ DSÖ 2017 Raporunda Türkiye'nin 2016 yılı insidans hızı yüz binde 18 ve TB mortalite hızı yüz binde 0,62 olarak verilmiştir. Türkiye'de Verem Savaşı 2017 raporuna göre 2015 yılı itibariyle ülkemizde 12.772 kayitlı TB olgusu bulunmaktadir. Bunların 11.803'ü $(\% 92,4)$ yeni olgudur. ${ }^{3}$

Mycobacterium tuberculosis'in sahip olduğu çok tabakalı hücre duvarı ve çok ilaca etkili dışaatım (efluks) pompaları, bakterinin doğal direncinin en önemli nedenleridir. ${ }^{4}$ Kazanılmış ilaç direnci ise uygun olmayan tedavi rejimleri ve hastaların tedaviye uyumsuzluklarına bağlı olarak dirençli mutantların artması sonucu gelișen dirençtir. Bunun sonucu olarak TB tedavisinde kullanılan ilaçlar da sınırlanmaktadır. ${ }^{5}$

TB tedavisinde primer ve sekonder olmak üzere iki grup ilaç kullanılmaktadır. Primer ilaçlar; izoniazid (INH), rifampisin (RIF), pirazinamid
(PZA), etambutol (ETM), streptomisin (SM) ve tiasetazon (T) iken, sekonder ilaçlar; Rifabutin, rifapentin, sikloserin, etiyonamid, amikasin, kanamisin, kapreomisin ve paraaminosalisilik asit, levofloksasin, moksifloksasin ve gatifloksasin gibi daha toksik ve daha zor tolere edilebilen ilaçlardır. ${ }^{6}$

M.tuberculosis'te oluşan kromozomal mutasyonlar tek basamakl1, rastgele ve spontan olup, genellikle tek ilaca karşı direnç oluşumuna neden olmaktadır. Ancak, birden fazla ilaca dirençli bakteriler de adım adım direncin birikimiyle ortaya çlkabilmektedir. Antitüberküloz ilaçlardan en az INH ve RIF'a karşı birlikte direnç olması durumu ÇİD TB olarak adlandırılmaktadır. ${ }^{?}$

Tüberkülozdan korunmada en etkin yöntem, hastaların erken tanısı ve tedavisidir. İlaca direnç sürveyansının yapılması TB kontrol ve tedavi programlarının temelini oluşturur. Literatürde son y1larda izole edilen M.tuberculosis $\quad$ suşlarındaki $\quad$ ilaç dirençleri ile ilgili bölgemize ait veri bulunmamaktadır. $\quad \mathrm{Bu}$ çalışmada, laboratuvarımızda izole edilen M.tuberculosis kompleksi izolatlarının primer antitüberkuloz ilaçlara duyarlılıklarının araștırılması ve direnç paternlerinin belirlenmesi amaçlanmıştır.

\section{MATERYAL ve METOT}

Çalışmada, 2012-2017 yılları arasında TB şüphesi ile laboratuvarımıza gönderilen 11194 
klinik örnek değerlendirmeye alınmıştır. Örneklerden üretilen MTK kompleksi izolatlarının primer antitüberküloz ilaçlara duyarlılıkları retrospektif olarak incelenmiştir. Laboratuvara gönderilen örnekler N-Asetil-LSistein (NALC) + Sodyum Hidroksit $(\mathrm{NaOH})$ yöntemi ile homojenizasyon ve dekontaminasyon sonrası konsantrasyon işlemi uygulandıktan sonra, üretici firmanın önerileri doğrultusunda BACTEC MGIT 960 (Becton Dickinson, ABD) sistemine ve LowensteinJensen besiyerine ekilmiştir. Steril vücut sıvıları da pH'sı ayarlanarak dekontaminasyon işlemi uygulanmadan besiyerine ekimi yapılmıştır. Tüm örneklerin kültür ekiminden sonra boyanmak üzere yayma preparatı hazırlanmıştır. Yayma preparatlar, Erlich-Ziehl-Neelsen (EZN) boyama ve fluoresanboya (auramin O) yöntemi ile boyanarak incelenmiștir.

MPT64 antijenini saptayan BD MGIT TBC Tanımlama Testi (Becton Dickinson, ABD) kullanılarak, üreyen bakterilerin MTK veya atipik mikobakteri olduğuna karar verilmiştir. Duyarlılık testleri; streptomisin, izoniazid, rifampisin ve etambutol (SİRE) kiti kullanılarak nonradyometrik bir yöntem olan BACTECMGIT 960 (Becton Dickinson, ABD) sistemi ile, üretici firmanın önerileri doğrultusunda gerçekleştirilmiştir. İzoniazid ve rifampisine birlikte dirençli olan izolatlar, ÇİD olarak kabul edilmiştir. İzole edilen suşlardaki duyarlılık oranlarındaki değerlendirmeler için SPSS 21.0 programı kullanılmıștır.

\section{BULGULAR}

Laboratuvarımıza gönderilen 11194 klinik örnek içinde 8390 (\%74) örnekle balgam örneği birinci sırayı almıştır. Diğer örnekler (steril vücut sıvıları, aspirasyon sıvıs1, biyopsi materyali, açlık mide sıvısı v.b.) 1213 adet (\%11) gönderilmiştir. Bunu 1121 (\%10) örnekle bronkoalveolar lavaj sıvısı örnekleri takip etmiştir. Bunların dışında 470 (\%4) idrar örneği değerlendirmeye alınmıştır.

Çalışmaya alınan 11194 örnekten $466(\% 4,1)$ tanesi M. tuberculosis kompleks olarak tanımlanmıştır. Yıllara göre MTK pozitifliğine bakıldığında 2012-2017 yılları arasında sirasiyla; $\% 4,5, \% 3,4, \% 3,5, \% 4,6, \% 5,4$ ve \%3,1 bulunmuştur (Tablo 1).

Tekli ya da çoklu ilaç direnci gözetmeksizin INH, RIF, SM ve ETM için hesaplanan toplam direnç oranları ise sırasıyla; \%9,8, \%4,1, \%7,7 ve $\% 4$ olarak bulunmuștur. $\mathrm{Bu}$ verilerde en yüksek direnç oranına sahip olan birinci seçenek antiTB ilaç INH'dır.

2012-2017 yılları için birinci kuşak antiTB ilaç direnci tekli düzeyde etambutol, izoniazid, streptomisin için sırasıyla Tablo 1'de gösterilmiştir. Tek başına rifampisin direnci saptanmamıştır.

En az bir antiTB ilaca direnç oranı \%14,8 olarak bulunmuştur. Çok ilaca direnç ise tüm örneklerde 19 izolatta ve $\% 4,1$ oranında bulunmuş olup, çoklu direnç daha çok 2012 yılında saptanmıştır. TB dışı mikobakterilerden 
ise tüm örnekler arasında 40 adet $(\% 0,4)$ izole edilmiştir.

\section{TARTIŞMA VE SONUÇ}

TB hastalarının erken tanısı, bu hastalara uygun tedavi rejimlerinin başlanılması ve tedavisinin takibi, TB kontrol programlarının en önemli unsurlarındandır. $\mathrm{Bu}$ nedenle uygun tedavinin belirlenmesinde MTK grubu bakterilerin üretilmesi ve antibiyotik duyarlılık testlerinin yapılması büyük öneme sahiptir. ${ }^{1}$

Antitüberküloz ilaçlarına karşı gelişen direnç, ülkemizde olduğu gibi dünyada da önemli bir sorundur. TB tedavisinde yetersiz ve/veya yanlış uygulamalar antiTB ilaçlara karşı dirençli MTK suşlarının artmasına neden olmaktadır. Yu ve ark.'nın çalışmasında, BACTEC MGIT 960 sistemi ile identifiye edilen 1961 izolatın 229 (\%11,7)'unun INH'a, 55 (\%2,8)'inin RIF'e, 49 $(\% 2,5)$ 'unun ETB'e, 218 (11,1)'inin SM'e dirençli olduğu bulunmuştur. ${ }^{8}$ Tilahun ve ark.'nın Etiyopya' da yaptığı başka bir çalışmada 105 solunum yolu örneğinde saptanan izolatlardaki direnç oranları; INH; $(\% 9,3)$, ETB; (\%7), SM; $(\% 5,8)$ ve RIF; \%1,2 olarak bildirilmiştir. ${ }^{9}$

Sağlık Bakanlığı'nca yayınlanan “Türkiye'de Verem Savaşı 2017 Raporu" nda ülkemizde 2015 yılındaki direnç oranları INH için; \%13,7, RIF için; \%5,4, ETB için; \%4,4, SM için; \%11,3 olarak verilmiştir. ${ }^{3} \mathrm{Bu}$ verilerde en yüksek direnç oranına sahip olan birinci seçenek bir
antiTB ilaç olan INH'dır. Türkiye'de yapılan çalışmalarda yeni ve tedavi edilmiş olgular birlikte ele alındığında, tek başına SM direnci; \%0-20, INH direnci; \%2-24, RIF direnci; \%0-10 ve ETB direnci; \%0-6 arasında bildirilmiștir. ${ }^{10-}$ 21

Çalışmamız verilerine göre 2012-2017 yılları arasındaki 11194 örnekten $466(\% 4,1)$ tanesi MTK olarak tanımlanmıştır. En az bir antiTB ilaca direnç oranı; \%14,8, çok ilaca direnç ise \%4,2 olarak bulunmuştur. Çalışmamızdaki direnç oranları INH için;\%9,8, ETB için; \%4 ve SM için; \%7,7 olarak saptanmıştır. RIF için tek başına direnç gözlenmemiştir. Ülkemizde yapılan çalışmalarda genel olarak INH direncinin yüksek olduğu gözlenmektedir. Çalışmamızda da ülkemiz verilerine benzer şekilde en yüksek direnç oranının birinci seçenek antiTB ilaçlardan olan INH'a karșı olduğu görülmüştür. $\mathrm{Bu}$ dirençte son yıllarda görülen artış her yeni TB vakasının antitüberküloz ilaçlarına dirençli olma olasılığının arttığı anlamına gelmektedir. Tedavi planlanırken bunun dikkate alınması gerekmektedir. Uygun olmayan tedavi (ilaç seçimi, erken ilaç kesme, tedaviye uyumsuzluk) sonucu nüks gelişen hastalarda gözlenen toplam ilaç direnci ülkemizde oldukça yüksektir. Çalışmamızda özellikle son yıllarda streptomisin direncinde görülen artışta da; hastaların tedaviye uyumsuzlukları ve hasta takiplerindeki düzensizlikler sebep olarak düşünülmüştür. Bunun yanında çalıșılan suș 
sayısı gerçek direnç durumunun tespitinde yetersiz kalmış olabilir. Daha çok izolatla, daha kapsamlı şekilde yapılacak ilaç duyarlılık test çalışmaları, bölgemizde gerçek ilaç direnç durumunun tespitinde yol gösterici olacaktır.

ÇIDD-MTK suşları gerek ülkemiz, gerekse diğer dünya ülkeleri için önemli bir sorun olarak karşımıza çıkmaktadır. ÇİD tüberkülozun tedavisi oldukça komplike ve pahalıdır. ${ }^{2}$ DSÖ’nün Çİ tedavisinde kullanılmasını önerdiği ikinci kuşak ilaçlar pahalı ve toksik olup, uzun sureli tedavi gerektirmektedir. Öte yandan, DSÖ 2017 raporundaki 2016 y1lı verilerine göre dünya genelinde yaygın ilaç dirençli (YID) tüberküloz olduğunu bildirilen olguların \%6,2'sinin (\%95\% CI: \%3,6-9,5) ÇİD olduğu bildirilmiştir. DSÖ 2017 raporundaki YİD kavramı; INH ve RIF direncine ilaveten bir fluorokinolona ve enjektabl bir ikinci kuşak ilaca (amikasin, kanamisin ve kapreomisin) dirençli olguları ifade etmektedir. YID tüberkülozlu olgularda tedavi süresi, hastanede yatış süresi, klinik komplikasyonlar, tedavide başarısızlık ve daha fazla mortalite görülmektedir. ${ }^{2}$

DSÖ 2017 raporundaki 2016 yılı verilerine göre ülkemizdeki ÇíD oranı yeni vakalarda \%2,9, tedavi edilmiş vakalarda \%16 olarak bildirilmiştir. Dünyadaki en yüksek ÇİD oranı yeni vakalarda $\% 50$ oranında (Saint Vincent ve Grenadinler Adaları'nda) saptanmıștır. Bunu Belarus (\%38), Rusya (\%27), Ukrayna (\%27) izlemektedir. Dünyadaki değişik ülkelerde yapılmış çalışmalarda da farklı sonuçlar görülmektedir. ${ }^{2}$ Çin'de yapılan ve 2007-2014 yıllarını kapsayan geniş kapsamlı bir araştırmada ÇID-MTK oranı; \%6,2 olarak bulunmuştur. ${ }^{22}$ Endonezya'da Lisdawati ve ark. \%5,4 oranında ÇİD-MTK bildirmişlerdir. ${ }^{23}$

Sağlık Bakanlığı'nın “Türkiye'de Verem Savaşı 2017 Raporu" verilerine göre 2015 yılında Türkiye'de ÇİD oranı yeni vakalarda; \%2,5, tedavi edilmiș vakalarda; \%17,8, tüm tüberküloz vakalarında ise \%4,1'dir. Ülkemizde Tüberküloz Laboratuvar Sürveyans Ağ1 (TuLSA) grubu tarafindan 2011 yılında yapılmış olan ve ülkemizdeki birçok TB laboratuvarı ve verem savaş dispanserinin katıldığı çok merkezli çalışmada tespit edilen ÇID-MTK oranı, \%3,5'tir. ${ }^{24}$ İki farklı çalışmada daha benzer sonuçlar elde edilmiş olup, İNH ve RİF direncinin birlikte olduğu ÇID-MTK oranı $\% 4$ olarak bildirilmiştir. ${ }^{12-25}$ Ayrıca ülkemizde yapılan diğer çalışmalarda da \%2,2-14,4 arasında çoklu direnç oranları rapor edilmiştir. ${ }^{14,25-28}$

Bizim çalışmamızda elde edilen verilere göre; tüm örneklerden 19 izolatta $(\% 4,2)$ ÇİD tespit edilmiştir. Elde edilen veriler ülkemiz verilerine benzer oranda bulunmuştur. 2012 y1lında ÇİD'in diğer yıllara göre daha yüksek olduğu görülmüştür. $\mathrm{Bu}$ durumun sebebi olarak; 2012 yılında ilimiz Verem Savaş Dispanseri tarafından tanı ve tedavi amacıyla takip edilen hastalardan alınan örneklerin bizim laboratuvarımıza gönderilmesi ve bu suşlardan 
kaynaklanan bir direnç yüksekliği olduğu düşünülmüştür. Sonraki dönemde Verem Savaş Dispanseri'nden laboratuvarımıza örnek gönderilmemiştir.

ÇiD TB tespiti, uzun bir tedavi süresi gerektiğinden önemlidir. Ancak tedavi başarı oranları düşüktür. Yapılan çalışmalarda RIF dirençli olguların \%90'ından fazlasında izoniyazid (INH) direnci de eşlik etmektedir. Bu nedenle RIF direncinin tespitinin ÇID-MTB suşlarının saptanması yönünden iyi bir belirteç olduğu ifade edilmektedir. ${ }^{29,30}$ Ayrıca RIF direncinin erken saptanmas1, tedavinin yönlendirilmesinde de önemlidir. RIF direnci, ÇİD'i temsili olarak gösterdiğinden dolayı, moleküler testler kullanılarak RIF direncinin tespiti çok ilaca dirençli TB hastalarını taramak için kullanılabilir. ${ }^{31}$ Ancak moleküler testlerde yanlış pozitif sonuçlar alınabileceğinden dolayı sadece moleküler test sonuçlarına dayanılarak RIF dirençli olarak tespit edilen hastalarda uygun antitüberküloz ilaçlarının seçimi, yanlış tedaviye neden olabilmektedir. $\mathrm{Bu}$ yüzden moleküler metotla saptanan RIF direnci, mutlaka antibiyotik duyarlılık testi ile doğrulanmalıdır. ${ }^{32}$ Nitekim RIF direncinin, çok ilaca direnci temsili olarak gösterdiği kabul edilmesine rağmen, bazı çalışmalarda RIF direnci saptanan hastalarda eşlik eden başka bir direnç tespit edilmemiştir. ${ }^{32}$

Bulgularımız, hastanemize başvuran hastalarda gerek tek ilaca dirençli, gerekse çok ilaca dirençli tüberküloz olgularının Sağlık Bakanlığı verilerinde belirtilen Türkiye ortalamaları ile benzer olduğunu göstermektedir. Ülkemizde yapılan çalışmalarda belirlenmiş olan ilaç direnç oranları homojen dağılım göstermemektedir. $\mathrm{Bu}$ durum; bölgeler arası sosyoekonomik düzey farklılıkları, çalışılan örnek tipleri, çalışmaya alınan hasta grupları ve çalışmalarda kullanılan yöntemlerin standart olmamas1 gibi nedenlerden kaynaklanabilir. Ülkemizde bölgelerdeki hasta bildirim sisteminin eksiklikleri nedeniyle TB prevalansının belirlenmesi oldukça zor olmakla birlikte son y1llarda bu konuda önemli bir ilerleme kaydedilmiştir. TB hastalığının tanısının konmasının yanı sıra antitüberküloz ilaçlara direncin belirlenmesi, tüberküloz kontrol programı ve tedavi takibi açısından önemlidir. Tüberkülozda yanlış ilaç kullanımı ve buna bağlı ortaya çıkan çoklu dirençlerin önlenmesinde, direnç paternlerinin her bölge ya da hastane için kayıt altına alınarak düzenli aralıklarla izlenmesi gerekmektedir.

\section{KAYNAKLAR}

1. Kıyan M. Mycobacteriacea. In: Ustaçelebi Ş, ed. Temel ve Klinik Mikrobiyoloji. 1. baskı. Ankara, Güneş Kitabevi; 1999:419-461.

2. Global tuberculosis report 2017. Geneva: World Health Organization; 2017. Licence: $\begin{array}{llll}\text { CC } & \text { BY-NCSA } & 3.0 & \text { IGO. }\end{array}$ http://www.who.int/tb/publications/global_re port/en/. Accessed August 7, 2018. 
3. "Türkiye'de Verem Savaşı 2017 Raporu”, Sağlık Bakanlığı Yayın No 1091, Ankara 2017

".https://hsgm.saglik.gov.tr/depo/haberler/ver em-savas-raporu-2016-

2017/Turkiyede_Verem_Savasi_2017_Rapor u.pdf. Accessed August 7, 2018.

4. Jarlier V, Nikaido H. Mycobacterial cell wall: structure and role in natural resistance to antibiotics. FEMS Microbiol Lett. 1994;123(1-2):11-18

5. De Rossi E, Aínsa JA, Riccardi G. Role of mycobacterial efflux transporters in drug resistance: an unresolved question. FEMS Microbiol Rev. 2006;30(1):36-52.

6. Mandell GL, Petri WA. Drugs used in the chemotherapy of tuberculosis, mycobacterium avium complex disease. In: Goodman \& Gilman's. The Pharmacological Basis of Therapeutics, McGrawHill.1996:1155-1169.

7. Durmaz R. Mycobacterium tuberculosis'de direnç sorunu. ANKEM Derg. 2005;19(2):107-110.

8. Chia-Chuan Yu, Chih-Yen Chang, Chun-Eng Liu, Li-Fong Shih, Ju-Hua Hsiao, ChangHua Chen. Drug Resistance Pattern of Mycobacterium Tuberculosis Complex at a Medical Center in Central Taiwan, 20032007. J Microbiol Immunol Infect. 2010;43(4):285-290.

9. Tilahun M, Ameni G, Desta $K$, et al. Molecular epidemiology and drug sensitivity pattern of Mycobacterium tuberculosis strains isolated from pulmonary tuberculosis patients in and around Ambo Town, Central Ethiopia. PLOS ONE. 2018;13(2):e0193083. doi: 10.1371/journal.pone.0193083.

10. Şenol G, Komurcuoğlu B, Komurcuoğlu A. Mycobacterium tuberculosis kokenlerinin antituberkuloz ilaclara direnç durumu. İnfeks Derg. 2004;18(4):441-445.

11. Şenol G, Coşkun M, Biçmen C, Erer OF. Aktif Akciğer Tüberkülozlu Hastalardan İzole Edilen Mycobacterium Tuberculosis Kökenlerinin İlaç Direnç Oranlarının Değerlendirilmesi. Klimik Derg. 2006;19(2):71-74.

12. Karadağ A, Tokac M, Guvenli A, Sunbul M, Gunaydın M, Sanic A. Klinik orneklerden izole edilen tuberkuloz basili kompleksinin major antituberkuloz ilaclara direnc oranları. ANKEM Derg. 2004;18(4):189-192.

13. Esen N, Gunduz AT. Dokuz Eylul Universitesi'nde izole edilen Mycobacterium tuberculosis izolatlarında ilac direnci (20002002). Türk Mikrobiyol Cem Derg. 2003;33(4):337-342.

14. Aydın O, Beğendik Comert F, Kulah C, Aktaş E, Sumbuloğlu V. Zonguldak ilinde izole edilen Mycobacterium tuberculosis suşlarının primer antituberkuloz ilaclara duyarlığının BACTEC MGIT 960 sistemi ile belirlenmesi. Türk Mikrobiyol Cemiy Derg. 2008;38(2):61-70. 
15. Arseven O, Eraksoy H, Uzun Y, ve ark. Doğu Karadeniz Bölgesinde tüberküloz ilaçlarına direnç durumu. Klimik Derg. 1995;8(2):63-67.

16. Zer Y, Cicek H, Mehli M, Bayıl S, Balcı İ. Gaziantep Universitesi Tip Fakultesi Hastanesi'nde 2004-2006 y1lları arasında tuberkuloz hastalarından soyutlanan mikobakterilerin antitüberküloz ilac direnci. Klimik Derg. 2007;20(1):20-22.

17. Orhan G, Zer Y, Balcı İ, Bayram A, Korkmaz G.

Mikobakteriyoloji laboratuvarında incelenen örneklerin retrospektif olarak değerlendirilmesi. Türk Mikrobiyol Cemiy Derg. 2002;32(3-4):225229.

18. Yaylı G, Sozen H, Ağalar C. Isparta yöresinden izole edilen Mycobacterium tuberculosis suşlarının antitüberküloz ilaclara duyarlılıkları. Türk Mikrobiyol Cemiy Derg. 2003;33(1):24-30.

19. Kurtoğlu MG, Keşli R, Terzi Y, Baykan M. Investigation of the susceptibilities of Mycobacterium tuberculosis complex strains to major antituberculosis drugs with BACTEC MGIT 960 system. Nobel Med 2011;7:42-48.

20. Taşbent FE, Doğan M. Konya ilinde klinik örneklerden izole edilen Mycobacterium tuberculosis kompleks suşlarının birinci seçenek antitüberküloz ilaçlara direnç oranları. Türk Mikrobiyol Cem Derg. 2016;46(4):165-171.
21. Özmen E, Aslan A, Uçar M, Aydın H, Y1lmaz A. Erzurum Bölge Tüberküloz Laboratuvarında İzole Edilen Mycobacterıum Tuberculosıs Kompleksi Suşlarının Primer Anti-Tüberküloz İlaçlara Direnç Oranları. ANKEM Derg. 2017;31(2):53-58. doi: 10.5222/ankem.2017.053

22. He XC, Zhang XX, Zhao JN, et al. Epidemiological trends of drugresistant tuberculosis in Chinafrom 2007 to 2014. Medicine (Baltimore). 2016;95(15):e3336. doi: 10.1097/MD.0000000000003336.

23. Lisdawati V, Puspandari N, Rif'ati L, et al. Molecular epidemiology study of Mycobacterium tuberculosis and its susceptibility to antituberculosis drugs in Indonesia. BMC Infect Dis. 2015;15:366.

24. Sezen F, Albayrak N, Özkara Ş, ve ark. Ulusal Tüberküloz Laboratuvar Sürveyansına İlk Adım; Ankara, 2011. Mikrobiyol Bul. 2015;49(2):143-155.

25. Artan C, Deniz E, Biraderoğlu H, Atan A, Artan MO. Solunum yolu örneklerinden izole edilen Mycobacterium tuberculosis kompleksi izolatlarının primer antitüberküloz ilaçlara duyarlılığının değerlendirilmesi. ANKEM Derg. 2013;27(4):179-183.

26. Aydın F, Kaklıkkaya N, Bayramoğlu G ve ark. Klinik örneklerden izole edilen Mycobacterium tuberculosis komplek suşlarının antibiyotiklere direnç oranları. Mikrobiyol Bul. 2011;45(1):36-42. 
27. Dündar D, Tamer GS. Mycobacterium tuberculosis kompleksi izolatlarının primer antitüberküloz ilaçlara direnç oranları. Klimik Derg. 2009;22(2):52-54.

28. Özekinci T, Özbek E, Gedik M, Temiz H, Atmaca S. 2001-2003 y1lları arasında izole edilen Mycobacterium tuberculosis suşlarında ilaç direnci. Türk Mikrobiyol Cem Derg. 2006;36(1):31-34.

29. Lawn SD, Nicol MP. Xpert ${ }^{\circledR}$ MTB/RIF assay: development, evaluation and implementation of a new rapid molecular diagnostic for tuberculosis and rifampicin resistance. Future microbial. 2011;6:10671082.

30. Kalokhe AS, Shafiq M, Lee JC, et al. Multidrug-resistant tuberculosis drug susceptibility and molecular diagnostic testing: a review of the literature. Am J Med Sci. 2013;345:143-148.

31. Chang K, Lu W, Wang J, et al. Rapid and effective diagnosis of tuberculosis and rifampicin resistance with Xpert MTB/RIF assay: a meta-analysis. J Infect. 2012;64(6):580-588.

32. Van Rie A, Mellet K, John M, Scott L, Page-Shipp L. False-positive rifampicin resistance on XpertH MTB/RIF: case report and clinical implications. Int $\mathbf{J}$ Tuberc Lung Dis. 2012;16(2):206-208. doi: 10.5588/ijtld.11.0395. 
Tablo 1. Yıllara göre antitüberküloz ilaçların M. tuberculosis kompleks izolatlarına etkinliği.

\begin{tabular}{|c|c|c|c|c|c|c|c|c|c|c|c|c|}
\hline \multirow{2}{*}{ Antitüberküloz profil } & \multicolumn{2}{|c|}{2012} & \multicolumn{2}{|c|}{2013} & \multicolumn{2}{|c|}{2014} & \multicolumn{2}{|c|}{2015} & \multicolumn{2}{|c|}{2016} & \multicolumn{2}{|c|}{2017} \\
\hline & $\mathrm{n}$ & $\%$ & $\mathrm{n}$ & $\%$ & $\mathrm{n}$ & $\%$ & $\mathrm{n}$ & $\%$ & $\mathrm{n}$ & $\%$ & $\mathrm{n}$ & $\%$ \\
\hline INH-SM-ETB duyarlı & 47 & 66,2 & 49 & 90,7 & 57 & 81,4 & 50 & 78 & 100 & 80 & 58 & 74 \\
\hline INH direnci & 4 & 5,6 & 2 & 3,7 & 7 & 10 & 2 & 3 & 8 & 6 & 5 & 6 \\
\hline SM direnci & 5 & 7 & 2 & 3,7 & 3 & 4,3 & 1 & 1,5 & 13 & 10 & 8 & 10 \\
\hline ETB direnci & 2 & 2,8 & - & - & 2 & 2,8 & 3 & 5 & - & - & 1 & 1 \\
\hline INH- ETB direnci & 1 & 1,4 & - & - & - & - & 5 & 8 & - & - & - & - \\
\hline
\end{tabular}

Çok ilaca dirençli

\begin{tabular}{lcccccccccccc}
\hline INH-RIF & 7 & 9,9 & 1 & 1,8 & - & - & - & - & - & - & - & - \\
INH-RIF- ETB & 3 & 4,2 & - & - & - & - & 1 & 1,5 & - & - & 1 & 1 \\
INH-RIF- ETB -SM & 2 & 2,8 & - & - & 1 & 1,4 & - & - & 1 & 0,8 & 1 & 1 \\
INH-RIF-SM & - & - & - & - & - & - & 1 & 1,5 & - & - & - & - \\
Toplam & 71 & 100 & 54 & 100 & 70 & 100 & 64 & 100 & 125 & 100 & 82 & 100
\end{tabular}

INH: İzoniazid, RIF: Rifampisin, ETM: Etambutol, SM: Streptomisin 